\title{
Application of Recent Technologies in the Concept of Modern Business
}

\author{
Danica Tadic \\ Ministry of Finance and Economy, Belgrade, Serbia
}

\begin{abstract}
In the era of over communications and hyper concurrency, people are overloaded with the offer of information, ideas, products, and services. Information is easy and unbelievable prompt available all over the world. Customers, concurrency, and innovators have immediate access to each other changes in technology, especially those in informatics and technology of communication are transforming the era of informatics to the era of knowledge. The aim of this paper is to make an overview of the most up-to-date novelties in technology, especially those that were enabled by ICT, as well as to direct to some of the potential of the future evolution in business process that is open to the innovations.
\end{abstract}

Keywords: ICT, economy of knowledge, internet economy, virtual company

\section{Introduction}

The tempo of changes and evolution of technology has considerably accelerated in last decades. Kotler and Kevin (2006) has defined the technology as the most important power in determining the human destiny. For example, just few years ago only small number of people had access to the mobile telephone, most of the population used fixed phone lines for communication. Today's digital phones are everywhere: almost everybody has the direct access to the local, national, and global connections. And that happened in one blink. Unambiguously, that tansformation was positive for the society, factories, and individuals. Nowadays and meanwhile even intermediate enterprises have well organized system of informations accessible to the strong applications capable to elaborate, analyse, and interprete data with no quantitative restrictions. The influence of ICT could be clustered in at least three different categories: economic, business, and social. Those three are intertwined, in the sense that what happens in one is the cause and consequence of what is going to happen in the other. Nevertheless, it is useful to evaluate them all separately. Business management contributed to the application of ICT in any organization enabling the access to the resources that are contributing to the improvement of efficacy.

In principle, appropriate usage of technology maintains two elements of improvement: efficacy and effectiveness. As for the efficacy, technology promotes improvements widening and evaluation of information at all level of organization and further lower the risk of error considerably. With regard to the effectiveness,

Danica Tadic, Ph.D. candidate, Directorate of Measures and Precious Metals, Ministry of Finance and Economy.

Correspondence concerning this article should be addressed to Danica Tadic, Mike Alasa 14, 11000 Belgrade, Serbia. E-mail: tadicdana@gmail.com. 
technology enables application of company resources in many ways, growth of efficacy of the tasks or processes, which are undertaken. Strategic technology turned out to be important part of business strategy and potentially competitive advantage or deficiency at the global trade.

\section{Crisis as the Opportunity}

The challenge is now more important because many counties are thinking about new models of growth and development after global economy crisis. This is the field where technology and especially ICT could play key role, even if there are no solutions to guarantee the success (World Economic Forum, 2010). One of the most sensible and casting strategic responsibilities of the management team is their capability to precisely predict the future. In any environment, access to the information in correct form and in time, for the executive management team enables development of effective and active vision of the future. All corporative leaders, no matter to the section of their businesses, enterprises they are responsible for or the size of the trade to support, must sooner or later make decisions in at three fields: to define the applications most appropriate for the improvement of the distinctiveness of the process; to select the equipment, infrastructure, and tools that are going to optimize; and to enable contribution of ICT for the business and model that are the best for the management of the technology available for the different characteristics of organization.

Key change in global economy concerns the change of the fundamental competitiveness' advantage of enterprises and functions of the management. Lowered costs of information's course, growth of the trade, liberalization of the trade of products and labor, deregulation of finances courses have put at the second level traditional sources of competitive differentiations and pointed at the new cores as the base in creating the values. That fundamental core concerns the development and usage of invisible property, where the knowledge, competency, and intellectual property rights are of the most importance. One of the key tasks of contemporary managers is to provide, develop allocate resources of the organization. Technology is the resource of the most importance for numerous organizations. To manage the resources to attain, maintain, and develop competitive advantage comprises integration of technology with the strategy of the enterprise.

The second key task of the manager is development and usage of the capacity of the innovation in the enterprise. Activities that are enrolling in the process of innovation in the company are complex and risky, unpredictable, expensive, and very often with the uncertain results concerning the trade success. Competitive advantage has relative dimension - that is the result of comparison of the activity of the company to the activity of the concurrency, as well as the absolute dimension, which is the result of the existence of the trade of the company product.

\section{Analysis of the Old Industrial and New Economy}

Having in mind that in the era of digital economy (economy of knowledge) knowledge represents the power, ICTs that are creating fast and easily, exchanges and application of knowledge, faster and much more then ever, represents the method of using that power the best way.

Data on trade, companies, and labor in old industrial economy and new economy of knowledge are presented in Table 1. If we look to the trade of old economy (column 2, cell 2) we can see that they are slow, linear, and predictable and magnitude based. On the other side, the acceptance of knowledge as the primary source of value in column 3 , cell 3 , brings new economy to the top of those that are managing the knowledge 
effectively, discovering, and combining the knowledge in new products and services faster than the concurrency. Internet changed fundamental nature of business and concurrency. New modalities of building, delivery of the products and services appeared and concurrency enabled that people became the most precious resource that were not properly exploited in companies. The comparison of companies in column 2, cell 5 shows that the old economy was based at the capital and automation. We can see that in the new economy, as presented in column 3 cell 6, all employees are the treasury of knowledge and central part of the company concurrency advantage, top management can not support on his own the competitiveness of the company. Only possession of skill of the management is not enough for the success in managing in nowadays business world. Companies should understand the difference between management and leading, and they should know how to integrate the two roles as to achieve the success in organization.

Table 1

Old Industrial and New Economy of Knowledge

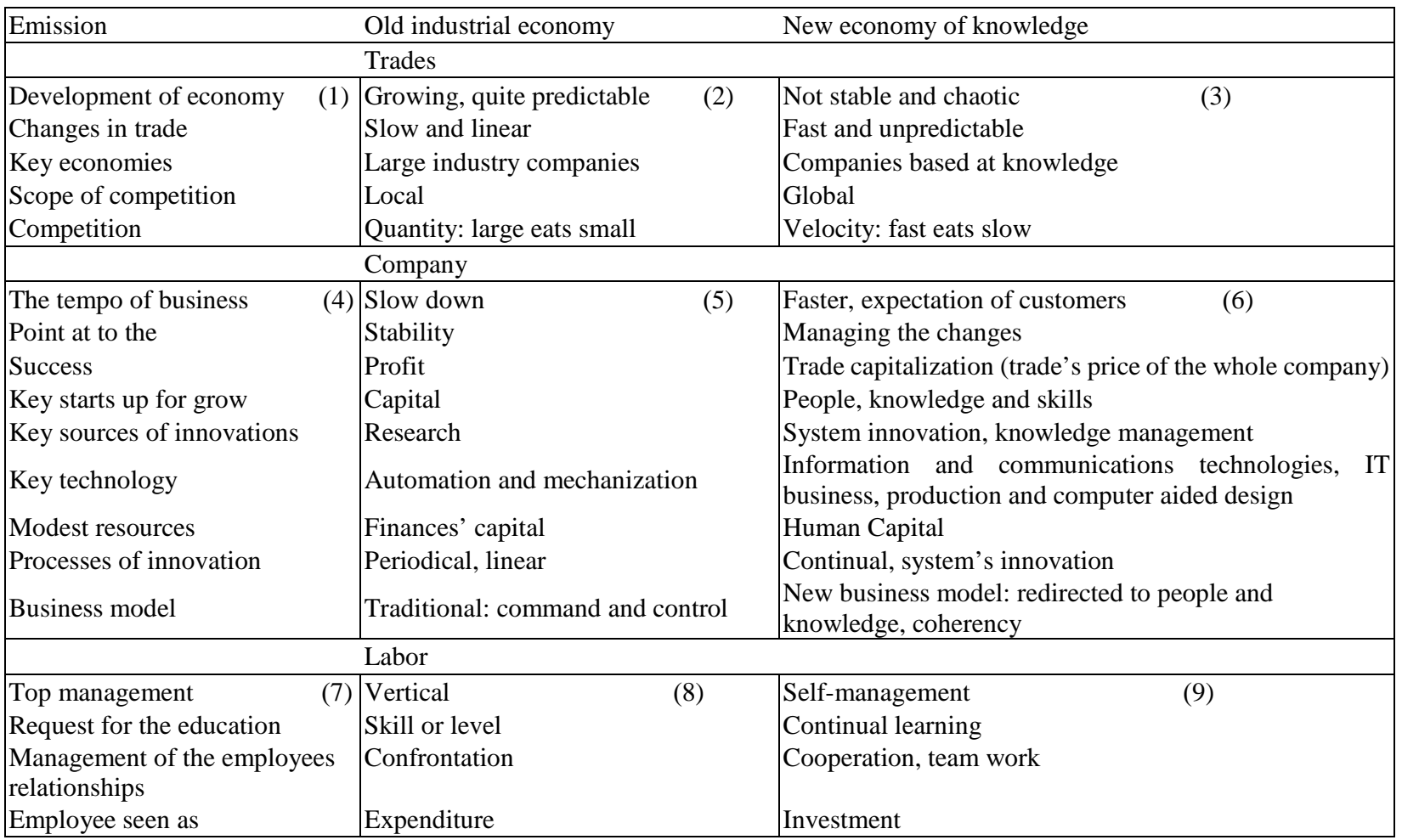

In the new era of fast changes and knowledge-based companies, management business became more difficult task. Technology and innovations have key role in increasing the productivity, development of new products, services and in creating absolute and comparable advantages. Internet technologies could play that role in supporting innovations' changes in design of the courses of business, as well as the requests of business and organigram in company. If we compare cells 8 and 9 at the level of the labor, there is a change in the approach of the company to their employees, greater attention is to the knowledge and capabilities. People become very important. System's opinion, capability to accept holistic point of view, including many different types or relations among multiple elements in complicated system, means overcoming largest obstacles in building business processes and success of the company in obtaining the results higher than the sum of the parts of the 
whole system. If you intend to become a new manager, you should understand that your art of working with people is the most important to build up. Your capability to influence the other and to motivate them to acquire corporative objectives is the most important talent of the manager.

Based on the previous analysis we can conclude that the new economy is characterized by the knowledge as the main component of the product and service, and that this is dramatically more ranked and became dominant component for the customer. Tempo of changes is so fast that the new companies are dominating and they completely marked the new era of the business that is based at knowledge, changes, and globalization (see Table 2).

Table 2

Three Powers of the New Economy Order

\begin{tabular}{|l|l|}
\hline Knowledge & $\begin{array}{l}\text { Intellectual value or capital as the strategic factor; set of comprehensions that are used by people in decision } \\
\text { making or undertaking actions important for the company }\end{array}$ \\
\hline Changes & Continual, fast, and complex; make uncertainty and lower prediction \\
\hline Globalization & $\begin{array}{l}\text { Technology, production, trade, finances, communication, and information are resulting in opening the } \\
\text { economy, global dependence, and business }\end{array}$ \\
\hline
\end{tabular}

Knowledge-faster transactions at the global trade, reconstruct the course of investments, goods, and services, changes in everyday's social and professional life of the people, growth of the quantity of the available information in private and public sector, as well as the consequences and usage of ICT are spreading faster. New ICT is the milestone of the development of the economy (society) of the knowledge and capability of the access to the ICT and their usage has the key role in the personal and social advancement. Instead of capital, information and knowledge became the base unit of individual and social growth.

Changes - tempo of progress in technology is faster and ICT became more present in behavior of the people in social nets, business praxis and in governmental activity. Dramatic changes in competition, technologies, labor, and values are provoking companies to search the new modalities in enlarging the production and concurrency. Possibility to access large information in only a few minutes, long distance communication at a lower cost, improvement of quality and practicality, transforms the way people communicate in companies.

Globalization-global internet economy enables faster growth in developing countries, faster expansion of their consumer's class and development of the wireless technology. Factors that are influencing especially to the spreading of Internet are: accessibility of PC and density of the existing fixed telephones. All over the world, technology can help to the people and to the individuals to realize ideas in reality and to overcome stagnation in development. Determined leaders are discovering coming business potentials and are strengthening employees through the inspiration and development of the net of possibilities. Inspired leaders create the culture in the frame of their organization. They create common vision and inspire people to attain more.

Motivated people are of the key importance to the development and execution of strategies, at all levels, supporting all big improvements.

\section{Knowledge as the Source of the Business Value}

In economy, where only certainty/uncertainty is the only certain source of the secret competitiveness' knowledge is the advantage. When trades changes, technology reproduce, competitors multiplies, and products becomes obsoletes almost over night, successful companies are the ones that are making new knowledge, spread the knowledge in the whole organization and model the knowledge in new technologies and products (OECD, 1996). Those activities define "knowledge-creation" companies whose only occupation is continual innovation. 
Many companies can create solely permanent competitive advantages if they turn into knowledge based companies or organizations where education/learning is of the most importance. They are using two kinds of knowledge. One is explicit knowledge, such as data, documents, and things written or memorized in PCs. The other kind is the concealed knowledge of the labor. This knowledge represents very often the most important information in organization. Long-term employee in company knows many things on production of the goods or offers of the services, as well as about the sale and how to work with the equipment. This silent knowledge is not documented or coded anywhere that knowledge had the evolution in the years of experience. In addition, large part of this silent knowledge employees do not share with the people in position that should screen them formally, as they are not enough motivated to do that, or simply "nobody asked them about it".

Successful knowledge management creates techniques, technologies, and system to encourage employees to share their knowledge. Knowledge management is becoming one of the main strategic applications of the IT. This information encompasses processes, procedures, patents, reference papers, formulae, best praxis, prognosis, and repair. Internet, Intranets, Web sites, Groupware are designed to support fast reverse information in the knowledge of the employees, to initiate changes in behavior of employees and to improve business performance. This integration helps the companies to become more innovative and faster provider of high quality products and services as well as very strong competitor on the trade.

\section{Internet Economy}

That is economy based at the digital technology, including digital net of communication (Internet, Intranets, as well as value added private nets_-VANS), PCs, software and other technologies of informatics. Digital connections and infrastructure of communication enabled global platform in which people and organization are in the position to work together, communicate, cooperate, and search the information. Development of the Internet economy in the near future will have as result the numerous new applications, services, and devices at disposal. All those will improve the quality of the people, growth of the productivity in the organization and provision of the foundations for the completely new business models, that could not exist without mobile Internet (World Economic Forum, 2010). New consumer's electronics, including smart phones, notebooks, tablet PCs, mobile media, video players, and book readers, facilitates widening the activities of users in the world, far away of their desks. Velocity in delivery of mobile and good quality wireless nets is improving all the time and will have a big jump with new generation of $4 \mathrm{G}$ net. 3G net are designed for voice and $4 \mathrm{G}$ net to launch data. Those innovations will be applied and in use of services that are location based, in order to improve the quality of the search, the communication tools, social nets, games, applications, and intended advertizing. Most likely, the highest influence to the economy will come over companies and other organizations that are adopting mobile wideband applications. Man workers, especially those in sectors such as transport, trade, health care, and some small sales, work far from the PCs that are connected to the internet. For dozen millions of workers that ate in their business mobile (such as taxi drivers, pilots, postman, traders, clerks, serviceman, building workers, worker in agriculture, ranchers, fisherman etc.), mobile internet enables them to connect to the powerful technology that were accessible only to the offices employees and the result of that is that all those will be put in the position to work with better efficacy.

Modern business models are in fact web based systems, whose applications or services are available from the 
server and as such are accessible from any place over Internet service (like World Wide Web) that is available in Web.

\section{Virtual Companies}

Information technology enables the companies to become partners with the providers, distributers, and producers. Cooperation over Web portal that is chain based system provision, significantly improve their capabilities in usage of innovative business possibilities.

In dynamic global business environment, the forming of virtual company could be one of the most important strategic usages of information technology. Virtual company (virtual corporation or virtual organization) is organization that is using information technology to connect people, organizations, means, and ideas (Martinez, Foultier, Park, \& Favrel, 2001). In virtual companies, virtual working groups are formed as well as the unions with the business partners that are connected over Internet, Intranet, and Extranet. It is notorious that those companies are organized internally in the process of clusters and cross-functional teams, connected in Intranet. They develop unions in external net of links that create inter enterprise information systems to the providers, customers, co-operant, and concurrency.

So, virtual companies create flexible and adaptive virtual working groups and unions that are of the key importance in exploiting the velocity in exchange business capabilities. Why people form virtual companies? That is the best way to conduct key business strategy and unions that offers promises for success in nowaday's business turbulence? For example, company can not have time or resources to develop necessary production, infrastructure of distribution, personal functions, and information technologies to make new trade capabilities to the full extent. Information technology can enable the company to develop relationships with their clients in virtual communities that are helping the company to become leading innovator. Nowadays, of course, internet, intranet, and extranet as well as many other internet technologies are vital components in creation of those successful solutions.

\section{New Dimensions in Business Area}

New values are the set of expressions to rate corporative performances in economy: speed at the trade, cycle period in development of new products, number of electronic connections to the providers, customers, and partners. In this new world the focus is put at the way the nature of values is changing, including the new price of the goods, information, and emotions. Implication of the new shapes of exchange is the transfer of the power from the producers to the customers. There are many present values: economic, informative, and emotive. Companies should think about the offer, including linkage of goods and services and to use the knowledge in order to provide added value to their customers, and not only the "sale of the service". User focused companies are using internet, intranet, extranet, e-commerce, and web locations to offer goods, services, and information always and in any moment, offering individual customer or user friendly service anywhere. The power of the punch of the technology, rise of economy, trade evolution, shift in customers' taste, social changes, and events in politics could widen or shorten business space. Potentials for innovators in technology or strategy are high, modern time produces great interruptions in continuity, create new industry, destroy old and accelerate growth in economy. Business space, technology, processes and models in business are becoming more complicated offering new possibilities for those that are entering new environment to create higher values. The power of customers has increased, the lack of goods and services is replaced with the abundance. The key reason for that is 
the fast development of the technology that enabled the growth of the production and productivity at lower cost. That enabled the entrance and spreading of industry of all kinds. At the same time, customers became more sophisticated and informed. Many products became virtual goods and fast changes in technology dramatically shortened the life cycle of products. The trade of capital evolved significantly. New investors are more informed, more innovative and active, and that is why they became the carriers of the changes demanding superior performance and corporative transparency. Concurrency is now more based at the capabilities than at the means. Simultaneously, knowledge labor became more mobile at the trade and old style of loyalty of employees has died. Due to the growing demography changes dual careers couples, family values, and free time.

From the customer point of view this process save money, increase pleasure, and give quicker results, from the manager perspective, the most important advantage of business is to safe expenses and time.

\section{Conclusions}

Based on the research that were conducted in this paper, it is possible to conclude that improvement of speed and quality of the wideband approach from the Web 2.0 technology and application, economy, and social dynamics will change dramatically all over the world, along with the large implications concerning productivity and new potentials for individuals. That concerns: creation of Internet economy, building of digital highways, guaranteed technologies, ICT influence to the lowering of poverty, ICT contribution to fulfill the decades' challenge, localization 2.0, and ICT effective social strategy. At the scene of nowadays, is so called game of null profit that is based on competition in which everybody has his own corridor to go up and improve. On the other side, new concurrency of brains storming is absolutely based on the principle: win or loose. In trade competition not everybody is using completely the same strategies, but it is quite evident that all players have the very same starting point.

Based on the dominant weapon that the concurrency is going to apply in 21st century will be education and skills of the employees, as well as the intelligence of the management. Digital economy, contrary to the industrial economy from the past, does not rely on natural resources, but on smart ambitious individuals.

\section{References}

Ahuja, M. K., \& Charley, K. M. (1998). Network structure in virtual organizations. Journal of Computer-Mediated Communication, 3(4), $1-34$.

Bjelić, P. (2011). Internet as the media and platform of contemporary business. Belgrade: Faculty of Economy.

Cisco \& Global Business Network. (2010). The evolving internet: Driving forces, uncertainties and four scenarios to 2025.Retrieved from http://www.monitor.com/Portals/0/MonitorContent/imported

IMF (International Monetary Fund). (2010). World economic outlook. Retrieved from http://www.imf.org/external/pubs/ft/

ITU (International Telecommunication Union). (2010). ICT indicators. Retrieved from http://www.itu.int/publ/

Kotler, Ph., \& Kevin, L. K. (2006). Marketing management. Belgrade: Data Status.

Martinez, M. T., Fouletier, K. H., Park, K. H., \& Favrel, J. (2001). Virtual enterprise-Organization, evolution and control. International Journal of Production Economics, 74, 225-238.

OECD. (1996). The knowledge-based economy. Paris: STI Outlook.

Palmer, W. J., \& Speier, C. (1997). A typology of virtual organizations: An empirical study. Proceedings from ACIS. Indianapolis, IN.

Qiang, C. Z. W., Rosotto, C., \& Kimura, K. (2009). Economic impacts of broadband. Information and communications for development 2009 (p. 45). Washington, D.C.: World Bank.

World Bank. (1998/1999). Knowledge for development. New York: World Bank and Oxford University Press.

World Economic Forum. (2008-2009). The global informationtechnology report: Mobility in a Networked World. Geneva: World Economic Forum.

World Economic Forum. (2010-2011). The global information technology report (pp. 33-34). WEF GITR 2010. 